\title{
Pengembangan hubungan interpersonal remaja dalam penggunaan media sosial di Kota Bandung
}

\author{
Cecep Darmawan ${ }^{1}$, Hana Silvana $^{2}$, Heni Nuraeni Zaenudin ${ }^{3}$, Ridwan Effendi ${ }^{4}$ \\ ${ }^{1,2,3,4}$ Universitas Pendidikan Indonesia, Bandung, Indonesia
}

\begin{abstract}
ABSTRAK
Pesatnya perkembangan teknologi Internet, membuat remaja menjadi kelompok digital native karena mereka tidak perlu diajari cara menggunakan teknologi tersebut. Kelompok remaja ini menjadi sasaran utama dalam literasi digital karena (1) dianggap paling rentan, dan (2) diharapkan menjadi agen perubahan untuk mengatasi berbagai problem masyarakat digital. Interaksi di dunia maya biasanya lebih mempererat hubungan juga dapat pula merenggangkan hubungan yang sudah terjalin. Tujuan penelitian ini adalah menggambarkan pengembangan hubungan interpersonal remaja dalam penggunaan media sosial menggunakan pendekatan kualitatif dengan metode studi kasus. Hasil penelitian menunjukkan bahwa setiap remaja mempunyai banyak identitas atau akun di media sosial, baik pada akun asli maupun akun palsu. Pada kenyataannya terdapat perbedaan antara pribadi di dunia nyata dengan pribadi di dunia maya. Efektivitas komunikasi interpersonal dipengaruhi oleh seberapa besar keterbukaan dari remaja yang sedang berinteraksi, sehingga dapat meningkatkan hubungan antar personal remaja tersebut, menjadi lebih dekat dan erat walaupun mereka berkomunikasi dengan menggunakan media sosial. Sikap remaja pada saat beriteraksi dengan orang lain dipengaruhi faktor eksternal dan faktor internal berupa kecerdasan emosional dan kepercayaan diri. Remaja membutuhkan pengembangan hubungan antar personal dalam berkomunikasi menggunakan media sosial.
\end{abstract}

Kata-kata Kunci: Remaja; komunikasi interpersonal; pengembangan hubungan; media sosial; literasi digital

\section{The development of interpersonal relationship among teenagers on social media in Bandung}

\begin{abstract}
The rapid development of Internet technology has made adolescents become native digital groups because they do not need to be taught how to use these technologies. This youth group is the main target in digital literacy because (1) it is considered the most vulnerable, and (2) is expected to be an agent of change to overcome the problems of digital society. Interaction in cyberspace is usually could create closer relationships but inevitably also stretch the already established relationships. The purpose of this study is to illustrate the development of adolescent interpersonal relationships in the use of social media using a qualitative approach with the case study method. The results show that every teenager has multiple identities or accounts on social media, both original and fake accounts. In reality, there is a difference between a person in the real world with a person in cyberspace. The effectiveness of interpersonal communication is influenced by how much openness of adolescents who are interacting in order to create an intimate personal relationship by using social media. Adolescent attitudes, when interacting with others, are influenced by external and internal factors such as emotional intelligence and self-confidence. Teenagers need social media as a mean of interpersonal relationship development.
\end{abstract}

Keywords: Youth; interpersonal communication; developing relationship; social media; media literacy

Korespondensi: Hana Silvana, M.Si. Universitas Pendidikan Indonesia. J1. Dr. Setiabudi No.229, Isola, Kec. Sukasari, Kota Bandung, Jawa Barat 40154.Email: hanasilva@upi.edu 


\section{PENDAHULUAN}

Penggunaan media daring (digital) atau media berbasis Internet mengalami peningkatan yang cukup pesat. Dampak yang dapat ditimbulkan dari media digital meliputi: cyberbullying, hoax (berita bohong), pornografi, kekerasan seksual, kecanduan terhadap kekerasan dan perceraian. Salah satu dampak lainnya yang juga harus diantisipasi adalah pernikahan di usia muda atau remaja. Hasil temuan Jaringan Penggiat Literasi Digital (Japelidi) menunjukkan bahwa remaja yang merupakan kelompok digital native dimana mereka tidak perlu diajari untuk dapat menggunakan Internet ketika mengakses informasi yang mereka butuh (Kurnia \& Astuti, 2017). Bahkan media sosial mampu meniadakan status sosial yang sering kali sebagai penghambat komunikasi. Kehadiran Twitter, Facebook, Google + dan sejenisnya mampu membuat orang-orang tanpa harus bertemu bisa saling berinteraksi (Watie, 2016).

Pengguna media sosial di Indonesia terhubung sebanyak $85 \%$ terhubung ke sosial media Facebook Group (Facebook, Instagram, WhatsApp Messenger) yang merupakan jumlah terbesar. Sebanyak 65 juta aktif menggunakan Facebook setiap hari dan 50\% bergabung di grup Facebook. Berdasarkan usia pengguna APJII menyebutkan bahwa mayoritas pengguna adalah berusia 18-25 tahun dengan jumlah hampir 50\%. Kategori ini memiliki karakter yang sangat aktif menggunakan teknologi digital dan mempunyai kecakapan dalam mengoperasikannya. Pengguna Instagram sebanyak 45 juta setiap hari dan jika dirataratakan mem-posting 2 kali lebih banyak dari global average (APJII, 2017).

Komunikasi merupakan aktivitas dasar manusia, dengan berkomunikasi manusia dapat berhubungan satu sama lain dalam kehidupan sehari-hari dimanapun manusia itu berada. (Wijaya, 2013). Komunikasi interpersonal melibatkan suatu bentuk aktivitas timbal balik (mutual activity), interaksi (interaction), atau pertukaran (exchange). Komunikasi interpersonal adalah pertukaran pesan di antara orang, dengan sebuah "pesan" menjadi perilaku orang lain, yang dimaksudkan atau tidak, dapat diinterpretasikan oleh seorang penerima tanpa batasan tentang jumlah orang yang terlibat pertukaran tersebut. Komunikasi interpersonal merupakan suatu perantara atau alat pendukung dalam bentuk bahasa lisan, bahasa tulisan, bahasa tubuh, dan lain-lain sehingga isi komunikasi dapat dipahami oleh penerima pesan (Pratiwi \& Sukma, 2013). Uraian tentang individu yang saling berkomunikasi dalam lingkungannya akhirnya menjadi media fardhu bagi manusia untuk menyampaikan idenya (Supratman, 2016). Semakin baik komunikasi yang dibangun antara orang tua dan remaja maka akan semakin menghindarkan remaja dari perilaku bullying. Anak remaja yang melakukan perilaku bullying di sekolah biasanya berasal dari keluarga yang broken home (Usman, 2013). Maka disinilah fungsi dari komunikasi interpersonal berada yaitu sebagai sharing ideas and knowledge antar manusia.

Komunikasi Interpersonal adalah komunikasi antarperorangan dan bersifat pribadi yang terjadi secara langsung (tanpa medium) ataupun tidak langsung (melalui medium) (Bungin, 2006). Komunikasi ini terjadi antara dua orang atau lebih dan sifatnya informal serta membutuhkan hubungan emosional di antara pelaku komunikasi. Komunikasi ini biasanya terjadi antara teman dekat, suami istri, sahabat serta orang tua dan anak, dengan kata lain individu yang memiliki hubungan emosional tinggi.

Penelitian pernah dilakukan oleh Gulam (2016) yang berjudul Studi Komunikasi Interpersonal dalam Keluarga Guna Mencegah Kenakalan Remaja di Kelurahan Baru Ulu Kecamatan Balikpapan Barat Kota Balikpapan. Penelitian tersebut menyebutkan bahwa kenakalan remaja dapat diartikan sebagai kenakalan anak-anak usia sekolah atau kenakalan sebagai pelajar (Gulam, 2016). Metode penelitian yang digunakan adalah studi deskriptif kualitatif. Hasil penelitian menunjukkan bahwa proses komunikasi interpersonal dalam keluarga tidak berjalan dengan baik. Tidak ada saling percaya antara orang tua dan anak, serta tidak ada sikap suportif orang tua terhadap anak sehingga komunikasi tidak berjalan dengan baik.

Penelitian yang dilakukan oleh Supratman berjudul Efektivitas Komunikasi interpersonal Guru dan Murid studi kasus pada TK Al Qur'an Al Ittihad Samarinda menunjukkan jika Pola komunikasi yang dilakukan manusia baik, maka komunikasi yang tercipta adalah komunikasi yang efektif (Supratman \& Rafiqi, 2016). 
Komunikasi memainkan peranan yang amat penting dalam pengajaran dan pembelajaran (Guat, 2013). Proses komunikasi berlaku dalam hampir segala jenis aktivitas pengajaran dan pembelajaran di dalam kelas. Pada umumnya komunikasi interpersonal terjadi karena pada hakikatnya setiap manusia suka berkomunikasi dengan manusia lain. Kegiatan komunikasi dilakukan sebagai upaya memenuhi kebutuhan untuk bekerja sama dengan orang lain. Tindakan kerja sama merupakan kesatuan dari komunikasi interpersonal yang efektif. Hasil penelitian ditemukan hambatan semantik dan hambatan manusiawi yang dialami oleh guru dilihat dari unsur keterbukaan yakni keberadaan murid yang pemalu dan acuh tak acuh sehingga menyebabkan kurang terbuka kepada guru. Selain itu pula kesetaraan yaitu masih ada murid yang merasa diperlakukan tidak sama dengan murid lain yang lebih pintar.

Komunikasi interpersonal tersusun dari banyak proses yang saling terkait, terdiri dari produksi pesan, pengolahan pesan, koordinasi interaksi, dan persepsi sosial (Berger \& Calabrese, 2014). Produksi pesan adalah proses menghasilkan perilaku verbal dan perilaku nonverbal yang dimaksudkan untuk menyampaikan suatu keadaan batin kepada orang. Pengolahan pesan meliputi menginterpretasi perilaku dan implikasiimplikasi perilaku mereka. Koordinasi interaksi adalah proses menyelaraskan aktivitas produksi pesan dan pengolahan pesan sehingga menghasilkan pertukaran yang lancar dan koheren. Terakhir, persepsi sosial adalah kumpulan proses-proses yang dijalani untuk memaknai dunia sosial, termasuk menyelami diri sendiri, orang lain, hubungan sosial, dan pranata sosial.

Tujuan komunikasi interpersonal yaitu: (1) Mendapat rangsangan, stimulasi ini dibutuhkan oleh setiap manusia, jika tidak manusia akan mengalami kemunduran dan mati sehingga rangsangan yang dimaksud disini yaitu kontak pribadi antara manusia; (2) Mendapatkan pengetahuan diri, Adanya kontak dengan orang lain membuat kita akan mengetahui diri sendiri dan menambah pengetahuan tentang diri kita sendiri melalui apa yang kita yakini dan orang lain pikirkan tentang kita; (3) Memaksimalkan kesenangan, dan meminimalkan penderitaan (Devito, 2013). Komunikasi yang dibangun antara kita dengan orang lain antara lain agar memaksimalkan kesenangan dan meminimalkan penderitaan karena berbagai rasa seperti emosi, nasib, penderitaan dan kesenangan menjadi keperluan dalam menjalani kehidupan.

Adler dan Rodman menjelaskan tipe-tipe komunikasi yaitu komunikasi verbal termasuk komunikasi vokal adalah bahasa lisan, lalu yang termasuk dalam komunikasi non vokal yaitu bahasa tertulis (Adler \& Rodman, 1985). Kemudian komunikasi nonverbalyang tergolong dalam komunikasi vokal adalah nada, suara, desah, jeritan dan kualitas vokal. Sedangkan yang termasuk klasifikasi komunikasi non vokal yaitu isyarat, gerakan tubuh, penampilan, ekspresi wajah dll.

Efektivitas antar pribadi dapat dilihat dari tiga sudut pandang, yaitu antara lain: a) Sudut pandang humanistik: pada sudut pandang ini menekankan pada keterbukaan, empati, dukungan, sikap positif dan kesetaraan. b) Sudut pandang pragmatis: dipusatkan pada perilaku spesifik yang harus digunakan oleh komunikator untuk mendapatkan hasil yang dikehendaki. Pada sudut pandang ini ditekankan pada lima kualitas yaitu: rasa percaya diri, kebersatuan, manajemen interaksi, daya ekspresi, orientasi pada pihak lain. c) Sudut pandang pergaulan sosial dan kesetaraan. Dipusatkan pada pertukaran manfaat dan biaya, serta implikasi dari pola pertukaran ini terhadap hubungan. Empat kualitas dari model pragmatis ini yaitu: bertukar manfaat, menanggung biaya bagian, mengintensifkan manfaat pada saat biaya meningkat dan memperbesar manfaat untuk mengurangi daya tarik alternatif (Kurniawati, 2014).

Hal ini sangat diperlukan dalam pengembangan hubungan antar pribadi sehingga dapat lebih meningkatkan hubungan dengan adanya faktor-faktor tersebut. Penelitian terdahulu yang sudah dilakukan menunjukan bahwa keefektifan komunikasi antar personal adalah berada di komunikator yang memiliki posisi penting sebagai salah satu komponen komunikasi yang membangun efektivitas komunikasi personal dengan anggota masyarakat (Bakti, Dewi, Romli, \& Budiana, 2015).

Devito menguraikan lima tahap dalam pengembangan hubungan. Kelima tahap ini adalah kontak, keterlibatan, keakraban, perusakan, dan pemutusan (Devito, 2013): (a) Kontak, pada tahap pertama terjadi pembuatan 
kontak. Pada tahap ini terjadi pemutusan apakah hubungan ini berlanjut atau tidak. Pada tahap ini penampilan fisik begitu penting, karena dimensi fisik paling terbuka untuk diamati secara mudah. Meskipun demikian, kualitas-kualitas lain seperti sikap bersahabat, kehangatan, keterbukaan, dan dinamisme juga terungkap pada tahap ini, (b) Keterlibatan, pada tahap keterlibatan adalah tahap pengenalan lebih jauh, ketika mengikatkan diri sendiri untuk lebih mengenal orang lain dan juga mengungkapkan diri, (c) Keakraban, pada tahap keakraban terjadi pengikatan diri lebih jauh pada orang tersebut, komitmen pada tahap ini mempunyai berbagai bentuk seperti: perkawinan, membantu orang tersebut, atau mengungkapkan rahasia terbesar anda, (d) Perusakan, pada tahap ini merupakan penurunan hubungan, ketika ikatan di antara kedua pihak melemah. Dan akan terasa bahwa hubungan tidaklah sepenting sebelumnya, dan (e) Pemutusan, pada tahap pemutusan adalah pemutusan ikatan yang mempertalikan kedua belah pihak. Jika bentuk ikatan adalah perkawinan, pemutusan hubungan dilambangkan dengan perceraian.

Dalam tahap persahabatan dan pertemanan biasanya muncul dari adanya kesamaan dan kepentingan yang terjalin selama menjalani suatu hubungan (Kurniawati, 2014). Interaksi yang dilakukan dan menyukai apa yang ditemukan di satu sama lain, mereka mulai menganggap diri mereka sebagai teman atau sebagai menjadi teman. Hal ini menjadi tahap awal yang baru lahir, seperti embrio, persahabatan. Pada tahap ini terdapat kriteria lain yaitu kepercayaan, yang mengukuhkan persahabatan. Setelah memperoleh kepercayaan banyak hambatan komunikasi yang akan ditemui seperti kurangnya komunikasi akan tetapi jika dapat melewatinya komunikasi dapat lebih terbuka. Ketika pertemanan mengalami perubahan atau memburuk diakibatkan karena kualitas dan kuantitas komunikasi. Temanteman menjauh dan mengalami sakit hati satu sama lain, mereka cenderung kurang sering berinteraksi dan berbicara tentang topik yang kurang pribadi dan konsekuensional.

Setiap hubungan bersifat unik. Begitu juga ketika membina hubungan karena alasanalasan yang unik. Empat alasan umum untuk pengembangan hubungan adalah mengurangi kesepian, mendapatkan rangsangan, mendapatkan pengetahuan diri, memaksimalkan kesenangan, dan meminimalkan penderitaan. Pertama, mengurangi kesepian dengan melakukan kontak dengan sesama manusia dapat mengurangi kesepian. Setiap individu memunyai kebutuhan akan kontak yang dekat, kadang secara fisik, adakalanya secara emosional, dan lebih sering keduanya; Kedua, mendapatkan rangsangan manusia membutuhkan stimulus. Kontak antar manusia merupakan salah satu cara terbaik untuk mendapatkan stimulus. Manusia membutuhkan stimulus intelektual, stimulus fisik, dan stimulus emosional; Ketiga, untuk mendapatkan pengetahuan diri (self knowledge). Sebagian besar melalui kontak dengan sesama manusia tiap individu bisa memahami dirinya. Persepsi diri sangat dipengaruhi oleh apa yang dipikirkan orang lain; Keempat, memaksimalkan kesenangan, meminimalkan penderitaan. Keempat alasan tersebut dapat menjadikan manusia merasa menjadi orang yang berguna dan meneguhkan kepercayaan diri sebagai makhluk sosial.

Pengembangan hubungan interpersonal tidak terlepas dari faktor-faktor lain yang mendukungnya. Salah satu faktor yang memberikan pengaruh terhadap pengembangan hubungan adalah faktor efektivitas komunikasi interpersonal. Devito menjelaskan bahwa efektivitas komunikasi interpersonal memiliki ciri-ciri sebagai berikut: Pertama, keterbukaan (openess), yaitu adanya keinginan saling menanggapi informasi yang diterima dalam hubungan interpersonal; Kedua, empati (empathy), merasakan apa yang dirasakan oleh orang lain; Ketiga, dukungan (Supportiveness), situasi terbuka dalam mendukung komunikasi agar berjalan efektif; Keempat, rasa positif (positiveness), seseorang memiliki perasaan yang positif dalam dirinya serta sering mendorong orang lain agar lebih aktif dan menciptakan situasi yang kondusif untuk interaksi yang efektif; dan Kelima, kesetaraan atau kesamaan (equality), sebuah pengakuan bahwa kedua belah pihak menghargai, berguna dan mempunyai sesuatu yang penting untuk dikembangkan (Liliweri, 2003). Dalam komunikasi interpersonal unsur keterbukaan merupakan bagian dalam meningkatkan hubungan. Berdasarkan hasil penelitian yang dilakukan oleh Pratiwi pada siswa di SMA Adabiah 2 Padang tentang sikap keterbukaan siswa mengenai kesediaan untuk membuka diri pada orang lain berada dalam kategori baik 
(Pratiwi \& Sukma, 2013). Keterbukaan siswa sudah mengacu pada keinginan siswa dalam mengungkapkan siapa dirinya pada orang lain. Selain itu pula kesetaraan merupakan suatu sikap yang menghargai setiap perbedaan seseorang. Komunikasi interpersonal akan lebih efektif jika suasananya setara yang artinya harus ada pengakuan secara diam-diam bahwa kedua belah pihak sama-sama bernilai dan berharga (Devito, 2013).

Penelitian yang dilakukan oleh Usman dengan judul "Kepribadian, Komunikasi, Kelompok Teman Sebaya, Iklim Sekolah dan Perilaku Bullying (Usman, 2013). Menunjukkan salah satu faktor remaja melakukan perundungan adalah akibat dari komunikasi interpersonal yang dijalin dengan orang tua dengan sarcasm akan cenderung meniru kebiasaan tersebut dalam keseharian. Kekerasan verbal yang dilakukan oleh orang tua akan menjadi contoh perilaku. Karena remaja dalam masa perkembangannya melakukan proses imitasi yang mengakibatkan potensi untuk melakukan perilaku bullying. Pada usia remaja faktor eksternal sangat mempengaruhi dalam perkembangan emosionalnya.

Nor Shafrin A dalam penelitiannya menemukan bahwa komunikasi interpersonal yang dilakukan oleh guru pelatih di dalam kelas ketika melakukan pengajaran mengalami kesulitan dalam memilih kalimat yang tepat, hal ini berkaitan dengan komunikasi lisan yang dilakukan (Ahmad, Amzah, \& Aman, 2009). Penggunaan intonasi dan suara yang monoton juga penyampaian yang tidak menarik. Ketika menyampaikan informasi yang penting tidak didukung oleh ekspresi yang sungguh-sungguh. Komunikasi lisan dan bukan lisan diperlukan dalam komunikasi interpersonal sehingga komunikasi dapat berjalan dengan baik.

Ketika melakukan proses komunikasi tentunya tidak terlepas dari hambatan yang ditemui. Menurut Giti Sudarmo dan Sudito upaya yang dapat dilakukan dalam menghadapi hambatan-hambatan dalam komunikasi interpersonal dapat dilakukan dengan cara (1) meningkatkan umpan balik; (2) empati; (3) pengulangan; (4) menggunakan bahasa yang sederhana; (5) penentuan waktu yang efektif; (6) mendengarkan secara efektif; dan (7) mengatur arus informasi (Bakti et al., 2015).

Salah satu cara yang cukup efektif dalam mengurangi misunderstranding dan miskomunikasi dalam komunikasi interpersonal adalah feedback atau umpan balik. Dalam konteks ini umpan balik berfungsi sebagai penegas atau konfirmasi apakah pesan diinterpretasi sesuai dengan maksud dan tujuan dari si komunikator.

Penyampaian pesan seharusnya disesuaikan dengan keadaan penerima dan pengulangan bertujuan menjamin bahwa pesan dapat diterima sehingga komunikan dapat memahami isi pesan yang disampaikan. Menentukan waktu yang efektif dalam melakukan komunikasi juga perlu diperhatikan agar pesan yang disampaikan dapat secara efektif diterima oleh penerima pesan.

Usia muda atau remaja adalah masa peralihan dari kanak-kanak ke dewasa yang dialaminya dalam tiga tingkatan yaitu usia pra remaja yaitu 10-12 tahun, remaja awal usia 13-16 tahun dan remaja akhir 17-21 tahun. Faktor eksternal pada masa ini mempunyai pengaruh yang cukup besar termasuk pula daya tarik media, faktor-faktor kebutuhan terhadap media dan manfaat yang dirasakan dalam mengonsumsi media (Hurlock, 2011). Faktor eksternal pada masa ini mempunyai pula pengaruh yang cukup besar termasuk pula faktor kecerdasan emosional dan kepercayaan diri yang merupakan faktor internal yang mempengaruhi sikap.

Pada tahun 1990-an yang lalu sulitnya berhubungan dengan orang yang berada di luar kota apalagi luar negeri. Tariftelepon sambungan jarak jauh dan internasional tergolong mahal. Untuk kalangan masyarakat tertentu tidak terjangkau. Surat merupakan alternatif lain agar hubungan komunikasi tetap terjaga. Tetapi cara demikian mengalami kekurangan yaitu waktu pengiriman yang lama. Pertimbangan lainnya tidak praktis ketika surat telah dibaca bisa jadi informasi yang didapat sudah usang atau tidak up to date.

Perkembangan Internet selanjutnya tidak hanya dimanfaatkan oleh perusahaan besar. Kebutuhan akan interaksi mempengaruhi kebiasaan masyarakat dari tradisional, modern ke post modernism. Perkembangan teknologi tahap keempat membuat hubungan dengan orang lain meskipun terpisah ribuan kilometer dan waktu yang berbeda semudah membalikkan telapak tangan dan mengedipkan mata. Media sosial adalah salah satu perkembangan teknologi yang memiliki andil besar dalam memberikan kemudahan bagi manusia untuk berkomunikasi 
dan bersosialisasi.

Perkembangan teknologi mengalami metamorfosis, media sosial diperkenalkan dengan Friendster dan Myspace. Kebutuhan interaksi yang lebih menuntut aplikasi yang variatif melahirkan Facebook dan Twitter serta yang terbaru adalah Google+. Media ini memicu perubahan manusia dalam bersosialisasi sesuai dengan tujuan awal mengapa media sosial dibuat. Antara lain memungkinkan pengguna berinteraksi dengan orang lain di seluruh dunia untuk mencari teman baru, pasangan hidup, berbisnis dan juga berpolitik.

Menurut McQuail seseorang yang menggunakan media massa didorong oleh empat motif, yaitu (1) informasi; (2) identitas pribadi; (3) integrasi dan interaksi sosial;(4) hiburan. Motif tersebut dipengaruhi juga oleh cara media massa mengemas sebuah informasi, sehingga informasi yang tidak bernilai pun dapat "tampak" bernilai jika dikemas dengan sedemikian rupa sehingga menarik minat audiens untuk menerima informasi tersebut (McQuail, 2003).

Penelitian ini bertujuan untuk menyajikan gambaran mengenai pengembangan hubungan interpersonal remaja dalam penggunaan media sosial. Hal tersebut didapatkan melalui penggalian terhadap upaya pengembangan hubungan interpersonal remaja dalam penggunaan media sosial di Kota Bandung.

\section{METODE PENELITIAN}

Penelitian ini dilakukan di Kota Bandung yang terbagi dalam beberapa wilayah yaitu Bandung Barat, Bandung Utara, Bandung Tengah, Bandung Barat dan Bandung Timur. Alasan melakukan penelitian di daerah tersebut karena ingin mengetahui gambaran terkait dengan pengembangan hubungan dalam penggunaan media sosial pada remaja di wilayah Kota Bandung. Hasil penelitian ini diharapkan mampu memberikan gambaran yang menjadi tujuan tersebut. Penelitian ini menggunakan teknik pengambilan sampel yaitu purposive sampling dimana pengambilan sampel penelitian ditentukan berdasarkan pada tujuan dari pengambilan informasi yang dibutuhkan. Teknik sampling ini tidak melihat latar belakang informan yang beragam sehingga perlu melakukan penarikan sampel secara acak tanpa memperhatikan strata yang ada. Metode penelitian yang digunakan dalam penelitian ini adalah pendekatan kualitatif dengan metode studi kasus. Metode studi kasus (case study) merupakan suatu penelitian yang dilakukan terhadap suatu "kesatuan sistem". Kesatuan ini dapat berupa program, kegiatan, peristiwa, atau sekelompok individu yang terikat oleh tempat, waktu atau ikatan tertentu. Studi kasus adalah suatu penelitian yang diarahkan untuk menghimpun data, mengambil makna, memperoleh pemahaman dari kasus tersebut. Pada Penelitian ini informan terdiri dari 6 orang kalangan usia muda. Adapun teknik pengumpulan data yang digunakan adalah wawancara. Peneliti melakukan wawancara mendalam, dimana peneliti mengajukan beberapa pertanyaan kepada informan untuk memperoleh informasi tentang masalah yang diteliti, yaitu berkaitan dengan pengembangan hubungan remaja dalam penggunaan media sosial. Pendokumentasian dilakukan dalam penelitian ini, peneliti juga mengambil datadata dari sumber lain berupa studi pustaka. Untuk mendapatkan informasi yang akurat penelitian ini melakukan triangulasi data. Data yang digunakan adalah triangulasi sumber dan studi pustaka. Sedangkan studi pustaka menggunakan literatur yang terkait dengan penelitian. Sumber data penelitian ini diperoleh dengan mengumpulkan data dari data primer dan data sekunder. Data primer diperoleh dari hasil wawancara dengan informan. Data sekunder berupa referensi dari tulisan-tulisan di koran, majalah dan buku-buku yang relevan.

\section{Tabel 1 Subjek Penelitian}

\begin{tabular}{llll}
\hline No. & \multicolumn{1}{c}{ Nama } & \multicolumn{1}{c}{ Usia } & \multicolumn{1}{c}{$\begin{array}{c}\text { Jenis } \\
\text { Kelamin }\end{array}$} \\
\hline 1 & Lusi Novianti & 16 tahun & Perempuan \\
2 & Rita Ameliana & 16 tahun & Perempuan \\
& P. & & \\
3 & M. Taufik F & 17 tahun & Laki-laki \\
4 & Luthfi Ifranda & 17 tahun & Laki-laki \\
5 & W. & & \\
6 & Zharfandy M. & 14 tahun & Laki-laki \\
\hline
\end{tabular}

Sumber: Hasil Penelitian 2018 
Pada penelitian ini informan terdiri dari 6 orang remaja. Pemilihan dari informan ini didasari oleh perwakilan usia yang termasuk ke dalam kategori remaja dan tempat tinggal yang mewakili wilayah di Kota Bandung.

\section{HASIL DAN PEMBAHASAN}

Dalam komunikasi interpersonal terjadi proses interaksi yang dilakukan oleh dua individu. Interaksi individu itu bisa diawali dari ketertarikan karena kesamaan dalam minat, tingkat sekolah maupun dari kesamaan hobi. Ketika dua remaja berinteraksi kecocokan bukan didasarkan pada ras, agama, etnik, gender dan status tetapi berdasarkan kepentingan dan ketertarikan. Di sisi lain dalam dunia maya individu cenderung akan dinilai atas idenya, bukan atas gender, ras, kelompok atau usianya. Seperti yang dikemukakan oleh informan bahwa:

"Saya menyukai hubungan dalam interaksi melalui Internet, ketika mempunyai interest yang sama terhadap sesuatu, hal tersebut membuat saya nyaman dalam berkomunikasi” (MT).

Dalam media daring, hubungan dapat terjalin dengan dimulai dari ketertarikan yang sama terhadap sesuatu hal. Selain itu pula kenyamanan mempengaruhi terhadap hubungan tersebut, dan hubungan tersebut dapat menjadi meningkat menjadi lebih erat.

Menurut pengakuan informan ZM, bahwa dia berteman di dunia maya adalah untuk mencari kenyamanan dalam berkomunikasi. Ketika pembicaraan sudah mengarah ke perdebatan, hal tersebut membuat ZM merasa tidak nyaman.

"Aku tuh cari temen di dunia maya untuk membuat nyaman, bukan untuk berdebat yang tidak jelas" (ZM).

Selain masalah kenyamanan dalam hubungan di dunia maya, ada hal yang menarik yang dilakukan oleh informan, seperti yang diungkapkan di bawah ini:

"Saya lebih suka menggunakan akun palsu, untuk menyamarkan identitas, tapi bukan bermaksud menipu, tapi supaya lebih nyaman saja berkomunikasi dan bisa lebih lugas dalam berdiskusi" (LN).
Menggunakan akun palsu merupakan salah satu cara untuk membuat nyaman dalam berkomunikasi di dunia maya. Dengan menggunakan akun palsu tersebut, dirasa lebih membuat komunikasi lebih lepas. Ketika pertemanan di media sosial terjalin dengan baik, timbul kepuasan tersendiri, bisa saling mendukung, men-support dan menyemangati walaupun tidak dapat bertemu langsung. Seperti yang dikemukakan oleh informan (SA):

"Mendapatkan teman yang cocok di Internet merupakan suatu kepuasan, saling mendukung walaupun tidak bertatap muka secara langsung" (SA).

Hal yang lain yang cukup menarik disampaikan oleh informan adalah bahwa komunikasi yang dijalin melalui media sosial justru lebih akrab dibanding dengan bertemu langsung atau bertatap muka langsung. Karena jika bertatap muka langsung kita akan melihat langsung ekspresi dari lawan bicara kita.

"Terkadang dengan berkomunikasi di dunia maya lebih akrab dibanding dengan bertemu langsung, mungkin karena tidak langsung melihat ekspresinya secara langsung ya...." (LI).

Informan RA mengemukakan bahwa dalam interaksi di dunia maya biasanya lebih mempererat hubungan juga dapat pula merenggangkan hubungan yang sudah terjalin.

"Aku pernah punya teman di Instagram, tapi ketika ada komen yang tidak mengenakan malah membuat jadi renggang hubungannya sama dia...." (RA).

Seperti yang diakui oleh informan (RA) terkait komunikasi personal secara online bahwa pertemanan yang terjalin akan menjadi tidak baik jika ada rasa ketersinggungan dari temannya terkait dengan postingan ataupun komunikasi yang dilakukan. Tapi berbeda pula dengan hal yang dialami oleh LN bahwa pertemanan melalui media sosial dan langsung mempunyai perbedaan yang tidak mengenakan. Seperti yang disampaikan berikut ini:

"Kalo Aku kapok punya teman dekat di Internet, karena sikapnya berbeda ketika bertemu di darat...." (LN).

Terdapat beberapa hal yang tidak dapat dipungkiri dalam berkomunikasi di jejaring 
sosial karena media sosial sudah menjadi kebutuhan yang berubah menjadi kebutuhan informasi yang primer bagi remaja.

Perubahan interaksi erat kaitannya dengan ilmu sosiologi. Pada Era Masyarakat industri dan Post Modern, teknologi di dunia maya atau cyberspace mengalami tiga tingkat pengaruh (Piliang, 2004). Tiga tingkat pengaruh tersebut antara lain pada tingkat individu, antarindividu, dan masyarakat.

Pertama, pada tingkat individu, dunia maya telah menciptakan perubahan mendasar terhadap pemahaman kita tentang identitas, setiap individu dalam dunia virtual dapat membelah pribadinya menjadi yang tidak terhingga batasnya. Sehingga, ada permainan identitas, identitas palsu, identitas baru, dan identitas ganda, yang bisa saja sama atau beda dengan identitas sosial di dunia maya.

Ketika berinteraksi di dunia maya seorang remaja menciptakan identitasnya sendiri. Hal tersebut memungkinkan jika dikaitkan dengan keterampilan penguasaan teknologi. Setiap remaja bisa mempunyai banyak identitas atau akun di media sosial. Baik akun yang resmi atau asli maupun akun yang palsu. Mengutip bahasa dari Piliang, seorang remaja bisa membelah identitas pribadinya menjadi jumlah yang tak terbatas. Perilaku tersebut menghasilkan permainan identitas antara identitas asli dan identitas palsu atau ganda.

Pada kenyataannya ada perbedaan antara pribadi di dunia nyata dengan pribadi di dunia maya. Jika mencoba memaparkan apa yang di bahasa pada buku virtual etnografi budaya yang dihasilkan setelah lahirnya sosial media adalah budaya pencitraan. Setiap remaja bisa menjadi identitas dengan pencitraan (remaja yang mengikuti fashion, remaja yang hobi travelling, remaja yang menjadi aktivis) sesuai yang dia kehendaki.

Komunikasi dalam media sosial terdiri dari level komunikasi intrapersonal, komunikasi interpersonal, komunikasi kelompok, komunikasi publik dan komunikasi massa. Setiap level memiliki ciri dan karakter tersendiri (Watie, 2016).

Kedua, pada tingkat antarindividu (interpersonal). Media sosial dapat mempermudah individu dalam berkomunikasi dan dapat berkomunikasi secara personal, rahasia melalui fitur direct message yang hanya dapat dibaca oleh mereka berdua. Selain itu kemudahan lain tidak adanya batas ruang dan waktu yang memungkinkan individu dapat mengakses media sosial kapanpun dan dimanapun.

Bertolak belakang dari keunggulan yang ditawarkan media sosial, terkandung didalamnya kerugian atau efek negatif dari penggunaan media sosial diantaranya: tumbuhnya sifat asosial dalam arti individu lebih menyukai berkomunikasi menggunakan media sosial dibandingkan dengan komunikasi di dunia nyata. Selain itu media sosial dapat menimbulkan efek ketergantungan yang akhinya akan menjadi candu, tiada hari tanpa membuka media sosial, bahkan hampir 24 jam mereka tidak lepas dari smartphone.

Media sosial terbesar yang paling berbeda dengan interaksi tatap muka atau interaksi melalui telepon di mana ada banyak petunjuk untuk mengidentifikasi identitas seseorang dan maksud mereka. Interaksi berlangsung dengan melakukan pengamatan raut muka, kerlingan mata, emosi, dan sentuhan. Seperti pembahasan pada kajian komunikasi interpersona dan komunikasi kelompok terdapat sinkronisasi antara bahasa lisan dan bahasa tubuh. Komunikasi interpersonal mensyaratkan keterlibatan penuh dari pihak yang terlibat (Watie, 2016). Jika salah satu menarik diri dari percakapan maka komunikasi interpersonal pun praktis akan berakhir. Jelas kondisi ini juga berlaku di media sosial. Dalam media sosial, komunikasi interpersonal dan komunikasi massa melebur menjadi satu. Saat seseorang mengunggah sesuatu kemudian ditanggapi oleh pihak lain, lalu terjadi interaksi, maka komunikasi interpersonal terjadi.

Media sosial yang sering digunakan oleh kalangan remaja antara lain: Facebook, Twitter, Path, YouTube, dan Instagram. Masing-masing media sosial tersebut mempunyai keunggulan khusus dalam menarik banyak pengguna media sosial yang mereka miliki. Media sosial memang menawarkan banyak kemudahan yang membuat para remaja betah berlama-lama berselancar di dunia maya. Pada konten media sosial pengguna Internet kebanyakan mengunjungi Facebook dan Instagram, pengguna Facebook sebanyak 71,6 juta dan Instagram sebanyak 19,9 juta. Jika melihat data tersebut maka menunjukkan bahwa masyarakat sudah dapat dikatakan bergantung pada media sosial (Mahardika \& Farida, 2019).

Banyak penelitian yang telah menyelidiki 
sejauh mana pengguna jejaring sosial atau SNS melakukan pengungkapan diri untuk menjaga pertemanan mereka dan juga memperluas hubungan yang lain. Kim dan Dindia menjelaskan bagaimana pertumbuhan interaksi sosial secara online dan dampaknya terhadap kehidupan pribadi (Ahmed, 2015). Konteks sosial dimana hubungan dapat dibentuk dan juga dibubarkan dengan mudah saat melakukan pengungkapan diri yang lebih besar.

Hasil penelitian yang pernah dilakukan mengungkapkan bahwa untuk kategorisasi aktivitas di sini di kalangan milenial Indonesia lebih dominan memanfaatkan Internet sebagai sarana berinteraksi sosial. Media sosial dan aplikasi chatting mendapatkan presentasi $67 \%$ diikuti mencari informasi dan browsing 47\% serta hiburan 41\%. Aktivitas mendengarkan musik, menonton film 30\% untuk kegiatan berbelanja dan bertransaksi perbankan bergerak/ mobile banking hanya $15 \%$ dan $18 \%$.

Ketiga, pada tingkat masyarakat (sosial). Pada tingkat masyarakat (sosial), ketika pembahasan beralih pada interaksi pada dunia maya dan terjalin interaksi online terdapat ketidakjelasan. Lawan bicara tidak mendapat gambaran sebagai referensi untuk memahami identitas seseorang. Namun demikian, minimnya tanda dalam interaksi online telah membatasi dan menjadikan interaksi lebih sulit dipahami (Dressang, 1999). Pengguna media sosial bisa saja meminjam identitas orang lain dan diklaim sebagai dirinya sendiri. Sebagai catatan berdasarkan pada observasi di lapangan ketika dua remaja berinteraksi kecocokan bukan didasarkan pada ras, agama, etnik, gender dan status tetapi berdasarkan kepentingan dan ketertarikan. Di sisi lain dalam dunia maya individu cenderung akan dinilai atas idenya, bukan atas gender, ras, kelompok atau usianya.

Stratifikasi sosial yang terbentuk pada masyarakat tradisional didasarkan pada kekayaan, pendidikan dan latar belakang keturunannya. Pada masyarakat maya, golongan masyarakat, pengelompokan masyarakat didaur ulang dan mengalami perubahan. Golongan tertinggi terbentuk karena banyaknya pengikut, banyaknya icon like, banyaknya komunitas yang dimiliki di media sosial. Golongan masyarakat akan diproduksi ulang dalam interaksi sosial dan bahkan semakin diperbesar ketika mereka membangun hubungan sosial di jejaring Internet.
Ketika remaja berinteraksi di media sosial, media sosial memiliki sisi plus dan minus. Hal tersebut merupakan karakteristik dari teknologi yang ambivalen atau seperti dua mata pisau untuk berinteraksi antara lain adalah Pertama, memudahkan remaja untuk berinteraksi dengan orang lain. Remaja di tahun 1990-an mengenal artis pujaan melalui kaset, koran, majalah dan video klip di televisi. Dengan lahirnya media sosial, para artis membuat akun pribadi dan mengelola media sosial tersebut oleh pribadi atau tim artis. Ribuan artis memiliki akun Facebook, Twitter dan Instagram. Remaja mengetahui kehidupan dengan cara berteman sehingga memungkinkan mengikuti kegiatan sehari-hari mereka dalam akun resmi. Pertemuan dua sahabat yang telah terpisah selama puluhan tahun dapat terjalin melalui sosial media. Pencarian cukup dengan menuliskan nama sebagai alamat dari orang tersebut. Ketertarikan komunitas pada satu kegiatan dapat diakomodir dengan membuat komunitas di media sosial. Kedua, memperluas pergaulan. Hasil wawancara yang telah dilakukan dengan remaja yang memiliki media sosial memungkinkan remaja menjalin relasi antar budaya dan negara. Media sosial membuat remaja bisa memiliki banyak koneksi dan jaringan yang luas. Media sosial seperti jendela untuk melihat dunia luar. Sharing pengetahuan dan informasi kerap dilakukan. Seperti pada pertanyaan yang sederhana menanyakan cuaca, makanan khas sampai kondisi sosial dan politik. Pengetahuan baru dari relasi berbeda budaya dan negara didapat dengan tidak melakukan kunjungan pada negara tersebut. Ketiga, lebih mudah dalam mengekspresikan diri. Beberapa hasil penelitian menjelaskan temuan media sosial memberikan sarana bagi manusia dalam mengekspresikan diri. Orang biasa dan pemalu, atau orang yang selalu gugup mengungkapkan pendapat di depan umum akhirnya lebih percaya diri untuk mengungkapkan diri yang sebenarnya. Media sosial memfasilitasi remaja yang memiliki ketertarikan pada bidang tertentu secara spesifik. Mereka dapat mencari teman di setiap negara yang memiliki hobi yang sama.

Selain memberikan nilai positif, hal yang harus diantisipasi adalah dampak negatifnya. Berikut adalah paparan perihal dampak negatif media sosial adalah mengabaikan kehidupan nyata dan orang di sekitarnya. Beberapa remaja rentang usia 13 - 21 tahun memberikan 
pengakuan berinteraksi dengan orang asing yang baru ditemui di sosial media dirasakan lebih tertantang. Rasa penasaran remaja akan jati diri lawan bicaranya membuat berinteraksi melalui sosial media lebih menyenangkan. Menghabiskan waktu dengan berselancar dan chatting berlangsung berjam-jam lamanya. Remaja sering menghabiskan waktu berinteraksi di dunia maya. Teknologi smartphone yang digenggam remaja memudahkan untuk mengakses Internet. Terdapat idiom yang terkenal untuk menggambarkan fenomena tersebut yaitu menjauhkan yang dekat dan mendekatkan yang jauh.

Selain itu pula, dari pengamatan pribadi, remaja rentan terhadap pengaruh buruk influencer di media sosial, yaitu akun pengguna media sosial yang memiliki banyak follower. Terutama dalam hal negatif seperti yang pernah ditunjukkan Awkarin di Indonesia atau anggota keluarga Kardashian. Semakin banyak remaja yang ingin mengikuti dan mengamati akun resmi para influencer di media sosial. Secara sengaja mereka menjual mimpi dengan memberikan gambaran kehidupan nyaman mereka. Seolaholah popularitas yang diperoleh secara otomatis tanpa adanya kerja keras. Kelemahan remaja di saat berada pada transisi harus mencari jati diri mereka mencoba membuat referensi model di media sosial. Proses imitasi dan adaptasi ingin menjadi apa yang ditawarkan oleh media sosial tidak bisa dipungkiri banyak terjadi.

Kekhawatiran mulai dirasakan jika yang menjadi referensi adalah artis media sosial yang memberikan pengaruh buruk. Artis media sosial yang memberikan referensi akan diperbolehkannya free sex, sarkastis, berpakaian seronok, pencandu dll. Maka dari itu keterampilan literasi media dan literasi informasi perlu diberikan pada kalangan remaja.

Masalah lain yang perlu diperhatikan adalah masalah pelanggaran privasi. Apa yang telah di-posting baik teks, visual atau video telah menjadi konsumsi publik. Maka dari itu tidak semua aktivitas dan privasi diberikan untuk dikonsumsi publik, terutama oleh orang yang tidak dikenal. Beberapa kejadian tidak menguntungkan apabila memiliki banyak teman di media sosial. Terlebih ada ungkapan yang seharusnya tidak diketahui orang lain. Jika tidak memanfaatkannya dengan benar, setiap teks yang ditulis, diunggah bisa dengan mudah dilihat orang lain. Akibatnya, hubungan dengan orang lain bisa renggang atau banyak remaja yang mengalami perundungan dari pihak lain.

\section{SIMPULAN}

Berdasarkan hasil penelitian diketahui bahwa dalam media daring, awal hubungan dapat terjalin dengan ketertarikan terhadap hal yang sama. Berikutnya, faktor kenyamanan dapat menyebabkan hubungan tersebut menjadi lebih erat. Pada interaksi kalangan muda atau remaja berbasis media sosial di Kota Bandung ini terdapat pengembangan hubungan pada saat komunikasi dilakukan secara intensif. Pada kenyataannya terdapat perbedaan antara pribadi di dunia nyata dengan pribadi di dunia maya. Efektivitas komunikasi interpersonal dipengaruhi pula oleh seberapa besar keterbukaan dari remaja yang sedang berinteraksi, sehingga hal tersebut dapat meningkatkan hubungan antarpersonal remaja tersebut, menjadi lebih dekat dan erat walaupun berkomunikasi menggunakan media sosial. Setiap remaja dapat memiliki banyak identitas atau akun di media sosial, baik akun asli maupun akun palsu. Tetapi hal ini tidak menimbulkan pengaruh yang signifikan jika hubungan interaksi interpersonal sudah terjalin dengan baik.

\section{DAFTAR PUSTAKA}

Adler, R. B. \& Rodman, G. (1985). Understanding human communication second edition. New York: Holt, Rinehart $\&$ Winston.

Ahmad, N. S., Amzah, F., \& Aman, R. C. (2009). Kemahiran komunikasi guru pelatih Universiti Sains Malaysia. Jurnal Pendidik Dan Pendidikan, 24, 125-142.

Ahmed, A. A. A. M. (2015). "Sharing is caring": online self-disclosure, offline social support, and social network site usage in the UAE. Contemporary Review of the Middle East, 2(3), 192-219.

APJII. (2017). Penetrasi \& perilaku pengguna Internet Indonesia 2017. Asosiasi Penyelenggara Jasa Internet Indonesia.

Bakti, I., Dewi, E. A. S., Romli, R., \& Budiana, H. R. (2015). Analisis faktor personal pada sumber komunikasi dalam pengelolaan tanaman obat keluarga di Jawa Barat. Jurnal Kajian Komunikasi, 3(2), 133-139. 
Bawden, D. (2001). Information and digital literacies: a review of concepts. Journal of Documentation, 52, 218-259.

Berger, C. R. \& Calabrese, R. J. (2014). Some explorations in initial interaction and beyond: toward a developmental theory of interpersonal communication. Human Communication Research, 1(2), 99-112. https://doi.org/10.1111/j.1468-2958.1975. tb00258.x.

Bungin, B. (2006). Sosiologi komunikasi edisi pertama. Jakarta: Prenada Media Group.

Devito, J. A. (2013). The interpersonal communication. New York: Peson Education.

Dressang, E. T. (1999). Radical change: books for youth in a digital age. New York: H.W. Wilson Company.

Guat, T. M. (2013). Komunikasi interpersonal dalam kalangan pelajar institut pendidikan guru semasa praktikum (interpersonal communication skill among pre-service teachers in education institude). Jurnal Penyelidikan IPG KBL, 2, 1-17.

Gulam. (2016). Studi komunikasi interpersonal dalam keluarga guna mencegah kenakalan remaja di Kelurahan Baru Ulu Kecamatan Balikpapan Barat Kota Balikpapan. EJournal Ilmu Komunikasi, 4(3).

Hurlock, E. B. (2011). Development psychology: a lifepan approach. Jakarta: Erlangga.

Kurnia, N. \& Astuti, S. I. (2017). Peta gerakan literasi digital di Indonesia: studi tentang pelaku, ragam kegiatan, kelompok sasaran dan mitra. Informasi, 47(2), 149-166.

Kurniawati, N. (2014). Komunikasi antarpribadi. Yogyakarta: Graha Ilmu.
Liliweri, A. (2003). Perspektif teoritis komunikasi antarpribadi suatu pendekatan ke arah psikologi sosial komunikasi. Bandung: Cipta Aditya Bhakti.

Mahardika, R. D. \& Farida. (2019). Pengungkapkan diri pada Instagram instastory. Jurnal Studi Komunikasi, 3(1), 101-117.

McQuail, D. (2003). Teori komunikasi massa: Suatu pengantar. Jakarta: Erlangga.

Piliang, Y. (2004). Posrealitas. Yogyakarta: Jalasutra.

Pratiwi, S. W. \& Sukma, D. (2013). Komunikasi interpersonal antar siswa di sekolah dan implikasinya terhadap pelayanan bimbingan dan konseling. Konselor, 2(1), 324-329. https://doi.org/10.24036/02013211268-000 .

Supratman, L. P. \& Rafiqi, A. (2016). Kajian etnografi komunikasi pada gaya berkomunikasi komunitas hansamo modern dance boys di Kota Bandung. Jurnal Kajian Komunikasi, 4(1), 1-9. https://doi. org/10.24198/jkk.v4i1.7852

Usman, I. (2013). Kepribadian, komunikasi, kelompok teman sebaya, iklim sekolah dan perilaku bullying. Humanitas (Fakultas Psikologi Universitas Ahmad Dahlan), 10(1), 49-60. https://doi.org/10.26555/ humanitas.v10i1.328.

Watie, E. D. S. (2016). Komunikasi dan media sosial (communications and social media). Jurnal The Messenger, 3(2), 69. https://doi. org/10.26623/themessenger.v3i2.270.

Wijaya, I. S. (2013). Komunikasi interpersonal dan iklim komunikasi. Jurnal Dakwah Tabligh, 14, 115-126. 